\title{
A man and his mic: Taking Chris Rock and Dave Chappelle to teacher's college
}

\author{
Laura Mae Lindo \\ Wilfrid Laurier University \\ decided@hotmail.com
}

\begin{abstract}
Taking seriously Donnell Rawling's advice that we need to interrogate our own "inner racism", this paper begins by examining work on anti-racism in North American education. Arguing that the narratives of diversity, equity, and social justice have paradoxically risen in prominence among educational researchers while their attempts to address equity issues in schools have simultaneously been resisted (Chase 2010), this paper advocates for the continued need to make discourses of race and racism explicit in educational settings (Lindo 2007, 2010, 2015; Solomon \& Levine-Rasky 2003; Bell 2009; Earick 2009). To this end, this paper presents and describes the work of "Race Comics" qua anti-racist educators and introduces the benefits of incorporating the comedic material of comedians like Chris Rock and Dave Chappelle in teacher education classrooms. Drawing on personal reflections of this pedagogical strategy in Canadian teacher education classrooms in Ontario (Canada) and Prince Edward Island (Canada), this paper teases out the ways in which these comedic texts in particular provided developing teachers with an opportunity to reflect upon their own normalised racial discourses, highlighting how these interfered with their ability to be the "perfect teacher". This paper concludes with a discussion of comedy's ability to help those devoted to developing socially just educational pedagogies to speak freely about their own normalised prejudices. In this way, "the man and his mic" facilitate explicit discussion of social inequities that, as critical race theorists like Derek Bell (1992; 2009) and Gloria Ladson-Billings (1995; 2009a; 2009b) have suggested, ensure that conversations about discourses of race and racism remain central in contemporary discussions about equity.
\end{abstract}

Keywords: anti-racism, comedy, pedagogy, race, teacher education, social justice pedagogies. 


\section{Social justice education and the challenge of making race and racism explicit}

While it is true that comedy creates spaces in public forums for discussions of race, gender, sexual orientation, religion and a large number of other controversial issues (Watkins 1994, 2002; Littleton 2006; Bell-Jordan 2007; Haggins 2007; Danesi 2008; Zoglin 2008; Lindo 2010, 2015), I contend that comedy does much more. For those who have devoted their professional careers to acting as "change agents", using comedy as a starting point for self-reflection on social justice issues helps practitioners to uncover their normalised beliefs - many of which, when left unspoken, serve to influence the ways that they interact with others in the world. This is especially true within the field of education where the pressure to conform to "social justice norms" includes insisting that teachers are free of bias, are socially just professionals, and advocates for equity and social justice in their classrooms and schools (Solomon \& LevineRasky 2003; Lindo 2010). Self-identification as a "Black Teacher", however, adds to this complexity in some very interesting ways. What follows is an academic tale - a story grounded in critical race theory and built on comedic foundations — of bringing comedians like Chris Rock and Dave Chappelle into my pre-service classrooms.

Early on in my teaching career, I knew that I was marked. As a Black female educator I had been warned by the likes of renowned scholars bell hooks (2003) and Annette Henry (2000) that it would be up to me to address racism in my classroom, simply because in traditional institutions my Black female body was presumed to be the best (and often the only) candidate for the job. And so for many years I struggled with this daunting task. The texts selected for students attempted to initiate "serious" discussions about how race structured our lived realities. While students tried to avoid talking about race in the classroom, I re-focused their attention by pointing out how race shaped the characters and stories we explored. The harder I pushed to have students reflect seriously on the role race played in their lives, the harder they pushed back. Nobody wanted to admit that they were racist, and students were enraged at having to re-live the guilt and shame of participating, even inadvertently, in racist acts. As the tension in the classroom grew, a sense of desperation began to set in - I needed to find another way to do this anti-racist work, and I needed it fast.

\section{Framing the story: Anti-racism, education and the paradox of resistance}

Traditional approaches to anti-racism education (ARE) ${ }^{1}$ consider overwhelming feelings of guilt, overt hostility, and unconcealed anger par for the course (Washington 1981; Solomon \& LevineRasky 2003; Lea \& Sims 2008; Earick 2009). Consequently, when theorists like Patrick Solomon \& Cynthia Levine-Rasky (2003) or Mary Earick (2009) discuss the counter-productive nature of experiencing these heightened emotions, they also presume that these overt emotional expressions symbolically represent the movement towards a deeper understanding of the "real life" effects of racial discourses. The "successful" anti-racist educator, then, must be prepared to work with overtly emotional responses as they arise. This interpretation of ARE resonates with the work of Lisa Woolfork (2009) who describes the benefits of a physical re-enactment of past traumatic events in order to provide a "more proximate knowledge of the past" (Woolfork 2009: 199). This bodily epistemology, Woolfork explains, helps to better inform moral and ethical codes of conduct (Woolfork 2009: 13). Citing Zora Neale Hurston in Their Eyes Were Watching 
God, Woolfork writes, "You got to go there to know there" (Woolfork 2009: 2). But do we have to "go there"? Must we be expected to undergo a traumatic process of re-living feelings of guilt and shame when discussing the consequences of racial designations and continued structural racism? I wanted to believe that there was another way, and as I compared and contrasted my own teaching practices to those examined in ARE literature, I became aware of a resource for ARE that I felt had been left un-tapped. That resource was laughter.

Over the years, as I have developed curricula for traditional and non-traditional classrooms settings ranging from elementary to post-secondary and graduate level courses, I have been fascinated by the spaces made in these settings to mobilise and initiate explicit discussions about racial discourses and the impact of racism in the contemporary world. Despite ongoing resistance by educators made uneasy by engaging in these discussions, it has become increasingly clear to me that thoughtful instruction in any classroom can and should create opportunities for students to re-think and re-evaluate hegemonic ideologies both within and outside of their school culture. But why are these discussions important? What can be gained from making talk of race explicit?

\section{The power of comedy's overt look at race: A new pedagogy is born}

The value of making discussions of race and racism explicit is immeasurable (DiFranco \& Eldridge 2013). An encouraging classroom, attentive students, critical discussions, re-assessment of our own subject position, the development of active citizens - all of these can be gained if spaces to discusses what Deborah Britzman (1998) has called "difficult knowledge" are promoted in schools (DiFranco \& Eldridge 2013; Lindo 2015). And while it is true that talking about race is not easy, I contend that this does not mean that it cannot be done. More specifically, I am suggesting that when it is done - when explicit discussions about race and racism are initiated - there is an alternative for educators who fear the need to contend with rising anger, hostility, and aggression among students and colleagues taking part in these discussions.

I have learned that starting with comedy can help.

While I taught in Canadian post-secondary settings in Ontario and Prince Edward Island, the inclusion of carefully selected comedic material allowed our classrooms to become spaces where each person experienced a moment where they laughed (or tried not to laugh) at images and comedic performances that were meant to be unsettling. And it was in these moments that some of our most poignant critical assessments about whether, if and how race stills matters arose.

In preparation for this novel approach, I delved into comedic scholarship and schooled myself in the art of talking about race through comedy. I noted that Black comedians in particular provided numerous commentaries on the state of race relations in their specific contexts. As I read more writing in this area and watched more comedy about race, I was taken by the amount of literature available which helped me solidify a clear distinction among the scholars of colour that I was watching. More specifically, where Black comedians and their work were examined with an eye to better explore how and why their comedy "worked", scholars like Bambi Haggins (2007) and Megan Sutherland (2008) created clear distinctions between those who incorporate critically astute discussions about race into their comedy from the rest of the comedic community (Watkins 1994, 2002; Haggins 2007; Sutherland 2008). Black comedians like Richard Pryor, Chris Rock, Dick Gregory, and Dave Chappelle appealed to mainstream (White) audiences as well as to audiences of colour. They were lauded for their artistic prowess, but it was the fact that they have been able to creatively challenge the racial assumptions of their spectators without ostracising the (White) audience members that gained them entry into the 
realm of comedic "high art". And yet, within this analysis, I also uncovered a paradox: many comedians who achieve such success (e.g., Richard Pryor and Dave Chappelle) have either claimed at some point in their career that their comedy is not to be considered political, or have had their work de-politicised by critics and reporters (Nachman 2003). For instance when Richard Zoglin (2008) argued that Richard Pryor resisted efforts to have his race-based comedy linked to Black political movements of the 1970s as he rose to fame, this stood in stark contrast to Pryor's own description of his comedic work. More specifically, Pryor discussed the creation of his comedic personae in overtly political terms through his infamous alter-ego Mudbone stating that, "I told him comedy — real comedy — wasn't only tellin' jokes. It was about telling the truth. Talking about life. Makin' light of the hard times. [...] The truth is gonna be funny, but it's gonna scare the shit outta folks" (Pryor \& Gold 1995: 6). Delving further into the development of his successful career in comedy, this overtly political stance became racially charged as Pryor explicitly contextualised his rise to fame within the reality of what it meant to be Black in the United States of America:

I saw myself as a victim of the system, an outsider for whom justice was out of reach, a dream, and then I saw how closely my situation mirrored the black man's larger struggle for dignity and equality and justice in white society. [...] I couldn't explain the transformation taking place. I don't understand it myself. I only know my days of pretending to be as slick and colourless as Cosby were numbered.

(Pryor \& Gold 1995: 92-93)

By 2013, in a documentary entitled Richard Pryor: Omit the Logic a new version of Pryor's story was being told — one that some may argue more accurately reflected Pryor's influence over generations of comedians. Comedians, comic writers, friends, and producers alike noted that Pryor's unique approach to comedy was grounded on the creation of highly politicised, and, more specifically, racially charged comedy routines, bringing to the stage the Black man's struggle in the (White) world. And Pryor was cognisant of what he was doing, stating in his autobiography Pryor Convictions (Pryor \& Gold 1995) that he could "stir up more shit on stage than in a revolution". With that as his starting point, by the late 1960s and early 1970s Pryor became "uncompromisingly Black" (Pryor \& Gold 1995: 117). To depoliticise Pryor's comedy, then, would be to disregard not only what he hoped his comedy could accomplish, but also to ignore the insurmountable influence he had on a generation of Race Comics who developed their abilities to write and perform politically savvy race-based comedy on public stages.

In response to these paradoxical efforts to depoliticise socially conscious race-based comedy, scholars like Katrina Bell-Jordan (2007), Bambi Haggins (2007), and Cris Mayo (2008) described the comedy of select Black comedians as deploying a strategic anti-racist pedagogy. For instance, Haggins (2007: 2), describing her work in the introduction of Laughing Mad: The Black Comic Persona in Post-soul America, explained that she is "offering detailed analysis of different personae (in their movement across mediums) and the varying ideological and pedagogical imperatives in their comedic discourse". By labelling the performance of Black comedians "pedagogy", she approached her analysis in a manner that both acknowledged and emphasised the political complexity of Black comedic performances. In this way, Haggins (2007) resisted traditional paradigms like Zoglin's (2008) that depoliticises the development of a Black comedian's personae. Moreover, as she extrapolated upon her analysis of comedians like Eddie Murphy, Chris Rock, Whoopi Goldberg, and Dave Chappelle within the socio-political realities of what she referred to as "post-soul America", 2 she emphasised how Black comedians 
make their audiences laugh while providing significant critiques of continued racial inequalities in North America (Haggins 2007: 13). Taking seriously the way(s) in which Black comedians contemplate and interpret contemporary racist ideologies, Haggins (2007), then, provided me with a solid foundation upon which to think about race comedy as anti-racist pedagogy.

Like Haggins (2007), Mayo (2008) also described her analysis of Black humour as an examination of the "pedagogical implications" of the social criticisms presented by Black antiracist performance artists who made intentional use of humour to initiate critical engagement with social justice issues. She argued that Black cultural practices and, consequently, the humour that developed in Black communities, suggested a novel approach to social justice work in the classroom: "[H] umour's meta- and indirect pedagogies can communicate a critique of white dominance, chip away at white certainty, and build oppositional community that lives in and argues through contingency" (Mayo 2008: 244). Humour, Mayo (2008) argued, was effectively used as a vehicle for social critique because the comedians intentionally engaged with social justice issues. I realised in this moment that it was the silencing of this politicised reading of performances by Black comedians that was troubling - the explaining away of any political significance that might be attributable to a comedian's incorporation of race and racism in his or her comedy. Thus, when Bell-Jordan (2007: 77), for example, theorised that Dave Chappelle's comedy should be considered as a "a system of learning, storing and transmitting knowledge", she, like Haggins (2007) and Mayo (2008), turned away from traditional interpretations of Black comedic work as mere entertainment, highlighting instead the possible benefits to furthering an understanding of contemporary racism that arose through a more serious examination of comedy.

Within these thought-provoking explorations, I felt it was important to speak to the idiosyncrasies of the comedian's race politics, using these as a catalyst to unpack interesting dialogues not simply about the comedy, but also about the racial discourses that structured the social world. Overt attempts to depoliticise this type of race-based comedic art, then, became clear examples of the manner by which ideological systems attempt to silence voices of Otherness. Efforts to belittle the political acts of racial "Others" pointed to another facet of systemic regimes of oppression that focused on diminishing the power of any artistic and creative endeavour that served to challenge systems of oppression. How were these moments of silencing the "Other" being addressed in comedic scholarship?

\section{The role of "race comics" in an anti-racist pre-service classroom}

It was these questions that excited me. I began to envision the unlimited critical possibilities of introducing my students to socially and politically astute comedians such as these. As I continued to search for my comedic qua pedagogical tools, what I discovered was a comedic trend - first in standup comedy circles, and later in sketch comedy as well - that shared similar goals with ARE thinkers. This particular group of comedians approached comedy in a way that ensured that race remained the primary focus of their comedic work. And as this "not-so-serious" pedagogy began to take form, I realised that there existed comedic techniques that educators could learn from. These Race Comics presented routines that represented much more than a stylised performance. Instead, they shared a common dedication to using their comedy to publicly critique racial discourses. The Race Comic acts in the public sphere in a way similar to "race wo/men" who had historically used their art to actively challenge racism (Carby 1998; Ramsey Jr. 2003), using a humorous rather than a more staid approach to interrogate hegemonic discourses of race. 
I was beginning to see how it might work, and I began to wonder: What if I took advantage of the moments where Race Comics pushed the boundaries of what was considered "acceptable" discourses about race? What would happen if I brought their art with me into the classroom as a method to help us collectively and individually explore why we were uncomfortable even as we laughed? From there, I could lead the discussion into a more in-depth analysis of how a particular moment in time was connected to the broader examples of racial dynamics and racist assumptions in the world outside of the classroom. And so, in this way, comedy provided me with incredible pedagogical tools that reconfigured the "safe space" of my classroom by encourage some very "unsafe" conversations. I had found a new pedagogical method for my anti-racist work — interrogating the self via race comedy.

It was this kind of pedagogical reading of particular Black comedians' texts that allowed for a distinction to be made between the work of Race Comics and the comedy of other Black comedians. But what is meant in this case by "pedagogical"? I argued that what separated Race Comics from other comedians was their critical look at racial discourses. By this I meant to do more that merely invoke a benign reading of "pedagogy" (i.e., pedagogy defined as "of or relating to teaching"). Instead my use of the term aimed to imply a critical pedagogical position - one that presumed that the pedagogue challenges their students (or, in the case of Race Comics, their audiences), taking them to a place of discomfort as described by Megan Boler \& Michalinos Zembylas (2003) in Discomforting Truths: The Emotional Terrain of Understanding Difference. In this work Boler \& Zembylas described the need to recognise our complicity in hegemonic inequities by taking the time to question normalised assumption. As described by Elizabeth de Freitas \& Alexander McAuley (2008), who made use of the theory proposed by Boler \& Zembylas (2003) to challenge pre-service teachers, "a pedagogy of discomfort aims to open possibilities for a more incomplete and ambiguous teacher identity that embraces difference as a source of creativity" (de Freitas \& McAuley 2008: 430). Likewise, Race Comics used their comedy to make visible the hegemonic racial ideologies society had normalised, bringing tensions and paradoxical social conventions to the attention of audiences. This "pedagogy of discomfort" then not only helped to support a political rendering of a Race Comic's performance, developed with a clear aim to challenge a racist social system, but also made explicit the connection between comedy by comedians like Richard Pryor, Chris Rock, or Dave Chappelle and the ongoing anti-racist work within the field of education (Means Coleman 2000; Haggins 2007; McNair 2007; Mayo 2008).

\section{Learning from race comedy: Three pedagogical principles - Validate, normalise and make explicit}

But what did this comedy look like? Race comedy included three principle elements. First, race comedy by Race Comics assumed that their audiences were critical thinkers interested in and capable of analysing and questioning the social norms within which they lived. And when a Race Comic used humour to re-focus audience attention on contemporary instances of racism, the performance was premised upon the assumption that the audience's insider status would result in a common interpretation of events. This suggested that the audience's ability to "get" the joke was the beginning step to making visible how racial politics oppressed some while empowering others. In this way, a Race Comic always assumed that their audience was adept enough to understand the nature of their race-based oppression. The Race Comic's positioning of his/her audience as "insiders" to the joke, then, did much more than simply create a moment of shared 
laughter. More importantly, the Race Comic validated their audience's intelligence by assuring them that the reason they were laughing — even when they giggled nervously — was because they understand both the joke and the socio-political realities that inspired the joke in question. This was apparent when Race Comics talked about White and Black relations or when they discussed normalised racial assumptions of Blackness within Black communities. Race Comic Chris Rock provided an excellent example of this phenomenon in his 1996 comedy special Bring the Pain (Rotenberg et al. 1996) and, more specifically, in his infamous sketch "Blacks".

In "Blacks", Rock introduced what he called the "civil war" among Black Americans - a war he described as being between "Black people" and "Niggers". Speaking directly to his audience, he explained:

Every time Black people want to have a good time, ignant'-ass niggers fuck it up! You can't do shit without some ignant' ass niggers fuckin' it up! [...] Hey, I love Black people, but boy I hate niggers.

(Rotenberg et al. 1996)

With his comedic set-up in place, Rock then launched into a detailed description of what distinguishes "Black people" and "Niggers", his argument being that "Niggers" tried consistently to be praised for things that "a regular man" knows he must do. Through the provision of various examples of differing perceptions of how a man would act if they were a "Nigger" and if they were a "Black man", Rock gave an account that distinguished between the two warring factions (e.g., by stating that the "Nigger" will say he takes care of his children, whereas "a regular man" knows that this is what he is supposed to do once he becomes a father). Rock explained further that the "Nigger" is proud of never having been incarcerated, using this as another example of the difference between them and a "Black man". Rock emphasises this distinction by exclaiming: "What do you want? A cookie? You're not supposed to go to jail low-expectation-havingmother-fucker!" (Rotenberg et al. 1996). In order for the joke to be well-received, Rock presupposed that the audience was able to understand (a) what distinguished good and bad behaviour, and (b) that the actions of the "Nigger" represented bad behaviour. With these two assumptions in place, Rock led his audience through an analysis, however brief, of the stereotypical assumptions about Black bodies that have resulted in particular behaviours being associated with the term "Nigger". Moreover, by proposing that Black people can also bring the behaviour of other Black people into question, Rock illuminated how he saw himself and his "insider" audience members — as a group of intelligent Black people who challenge and, to some degree, transcend, Black racial stereotypes. Rock not only proposed that he was much too intelligent to be dismissed as just another "Nigger", but he also implied that the same is true for his audience who were intelligent enough to take part in this discussion alongside him.

Like Rock, Race Comic Dave Chappelle assumed his audience to be comprised of knowledgeable insiders to the jokes being performed. That his audience does, in fact, consist of many insightful comedy lovers was revealed when comedians Charlie Murphy and Donnell Rawlings mediated a live studio audience conversation about the role of comedy in contemporary America in the 2006 release of the controversial DVD The Lost Episodes (Central 2006). What made this broadcast problematic was that it featured the final skits performed by Chappelle before he walked away from a fifty-million-dollar contract with Comedy Central skits that prompted him to publicly contemplate whether or not his comedy challenged or supported racist ideologies. What was important about this segment was not the comedic performance by Chappelle, but rather the conversation that developed among audience members as they were invited by Murphy and Rawlings to participate in a critical discussion that explored 
the effects of comedy like Chappelle's on the larger Black community. This public discourse presented commentary from many critically astute audience members who took advantage of this opportunity to examine the role comedy and comedic performances can and should play in society as well as consider whether or not the topic of race within comedy negatively or positively impacted multi-racial social interactions (Central 2006). For example, audience members provided the following commentary:

... he's done his research. And ... if he touches you to the point where you think about it, I think the mission is done.

(Central 2006)

You see a movie like Crash, and that's like really preachy, I feel. But then you see a sketch like this, and it gets people talking and laughing, so as long as we're thinking about it, it's a good thing.

(Central 2006)

The inclusion of audience comments like these on a DVD that would ultimately reach millions of viewers, I surmise, encouraged viewers at home to engage in critical dialogues about the same, using the live-to-air discussions from the audience as the starting point for their own critical contemplations about race, racism, and comedic performance.

A second necessary element for race comedy was the Race Comic's ability to normalise Blackness for their audience. In the words of Virginia Lea \& Erma Jean Sims (2008), Race Comics were "educulturalists", using the art of comedy as a means of "[facilitating] the unlocking of our unconscious minds, to interrupt the often ethnocentric, racist, classist, and sexist assumptions that lie sealed in that space. Through art, we are given insight and voice" (Lea \& Sims 2008: 18). Race Comics provided controversial insights into how racism permeates society, normalising for audiences a perspective on reality that is typically overlooked, devalued, and silenced. The Race Comics' assumption that Black experiences were "the norm", afforded them unlimited opportunities to use their comedy to challenge hegemonic racial discourses. Ultimately, by sanctioning "Black" interpretations of life experiences, Race Comics drew attention to the racist acts that Black people encounter on a daily basis. Although the comedic stories told by Race Comics offered a Black perspective that is often unpredictable, Race Comics were able to both demonstrate their own cultural competence and simultaneously support the development of the same in their audiences. I began to ponder what it really meant to "get the joke". It was no longer about superficial laughter, but about publicly acknowledging social injustice through that "getting of the joke" in ways that validated the lived realities of Black people and their communities. Like an ARE scholar, the Race Comic used their comedy to remind the audience that racism continued to permeate the social structures of everyday life, and, by walking audiences through their public analysis of how racism continued to frame what a person was allowed and not allowed to do, the Race Comic helped audiences develop their own cultural competence. The ways in which Race Comics presented the marginalised perspective on life was aptly demonstrated by Paul Mooney's (1993) commentary in his audio recording Race when Mooney discusses the ease with which it is believed that Black people are commonly involved in illegal activities:

Didn't some White man in Boston shoot his pregnant wife? And then shot himself, trying, "Oh, niggers did it!" Always tryin' blame some niggers. And they believed the shit! To the brother, couldn't take it or somethin' and he could ... he jumped off a fuckin' bridge, right? Then they told. 
Ain't that a bitch? Always tryin' to blame a goddamn nigger. That's why I'm ... I'm gonna ... I'm gonna start a ... a ... a new ... add: 1-900-Blame-a-Nigger.

[Rising audience laughter].

No! So when White folks get in trouble, just call my agency.

[Mooney Sobbing]

"Blame-a-Nigger? I just pushed my mother down the stairs. I don't wanna go to jail. Send a nigger over here!!"

"Alright, I got one on parole, I'll send him right over Ma'am."

[Mooney laughing with audience]

"Hello Blame-a-Nigger? I just ran my car into a tree - my whole family's dead! I don't want to be blamed. Get a nigger! Get a nigger!"

[Mooney laughing with audience]

"Yeah, we got one here with a bad driving record. I'll send him right over."

"Oh thank you! Thank you! God bless you Blame-a-Nigger!"

(Mooney 1993)

Here, Mooney (1993) provided his audience with examples of a singular role Black people continue to play in American society - that of culprit or scapegoat. Although the necessity of a "1-900-Blame-a-Nigger" hotline appears, at first glance, to be an absurd proposition, his use of a real example in which a Black person was falsely accused by a White person for a crime they did not commit - pointing out that people are "always tryin' to blame a Nigger" - provides a persuasive rationale for his "solution" to the continued scapegoating of Black people by Whites. The creation of a hotline would ensure that the "Nigger" who is sent to the scene of the crime is aware of what s/he will be blamed for, and leaves the audience assuming that the "Nigger" has agreed to act as the scapegoat in such instances. Moreover, Mooney's hotline would decrease the unfortunate occurrences in which the "Nigger" being blamed becomes overwhelmed by the false accusation and/or - like the Black male used to contextualise the joke - commits suicide. Taken as a whole, Mooney's "solution" would provide a means for dealing with the condemnation of innocent Black people in a way that treats the consequences of such false accusations with great seriousness. While on the surface it appeared that the hotline would only serve the needs of White Americans, further reflection revealed that Black interests were addressed by first acknowledging that this type of behaviour continues to affect Black Americans, and since White Americans continue to blame Black people for their illegal behaviour, the best course of action is to prepare for this unfortunate social role.

A number of cases similar to the one presented by Mooney to contextualise his comedic performance exist - a point that adds to the significance of the joke. For example, on 30 August 2010, Bethany Storro alleged that an unidentified Black woman threw acid in her face. As media attention increased, Storro received monetary gains from fundraising initiatives to help her as she healed from the severe burns. She later recanted her story and admitted that she threw acid in her own face in an attempt to commit suicide (Jabali-Nash 2010). In April 2010, Philadelphia Police Officer Robert Ralston intentionally shot himself, claiming that an unidentified Black man was the primary suspect. After his accusations were proven to be fabricated, he was suspended for 30 days and made to pay back the funds used to deploy a massive manhunt for the fictional suspect (Reporter 2010). In 1995, Susan Smith alleged that a Black man stole her car with her children still inside, and drove the car into the river where her children drowned. It was later proven that she had in fact drowned her own children and the manhunt for a Black assailant was wholly based on lies (Gardener 2014). 
A third, and what I readily believed was the most important necessary element of race comedy was the attentiveness portrayed by Race Comics to make instances of racism visible for their audiences. Race Comics needed to create Black "insiders" of their audience members in order to normalise their experiences through comedic storytelling. This also provided them with an opportunity to illustrate for their audiences how racism organised the contemporary world. To do this, they often shared humorous narratives based upon their personal encounters with racism. And it was in these precious moments that they were able to make racist discourses visible for their audiences. This technique allowed the comedian to "prove" that racism was still a fundamental aspect of the day-to-day structuring of society and became a useful tool for supporting the development of their audience's sociopolitical perspective. Thinking again of the skilful work of Chris Rock, I became more and more convinced of the importance of this particular element of race comedy. Chris Rock demonstrated a Race Comic's ability to acknowledge and reflect upon continued racial inequalities in American society in various comedic performances, but for me, none as explicitly as when, in his $2008 \mathrm{HBO}$ comedy tour Kill the Messenger (Callner \& Rock 2008), Rock explained to his audience that in spite of his material wealth, he was still forced to negotiate the racist structuring of society like all other Black Americans:

And race is the big issue. The biggest issue in the world right now: Race. It's a big thing, man. Racism - all over the world. It will never die. It will never die - it will only multiply, baby. Racism. All over the world. Even in my life, there's some racism. People go, "Really?" Yeah, yeah. Yes, in my life. I'll ... I'll give you an example of how race affects my life, okay?

I live in a place called Alpine, New Jersey. I live in Alpine, New Jersey, right? My house costs millions of dollars. [Rising audience applause] Don't hate the player — hate the game. [Audience erupt with applause]

In my neighbourhood, there are four Black people. Hundreds of houses - four Black people. Who are these Black people? Well, me, Mary J. Blige, Jay-Z, and Eddie Murphy. Only Black people in the whole neighbourhood. So ... so, let's break it down. Me? I'm a decent comedian, I'm alright. Mary J. Blige ... Mary J. Blige - one of the greatest R \& B singers to ever walk the earth. Jay Z one of the greatest rappers to ever live. Eddie Murphy — one of the funniest actors to ever, ever do it.

Do you know what the White man that lives next door to me does for a living? He's a fuckin' dentist. [Audience laughter]

He ain't the best dentist in the world. He ain't going to the dental hall of fame. He don't get plaques for getting' rid of plaque. He's just a yank-'yo-tooth-out dentist. See, the Black man's gotta' $f l y$, to get somethin' that the White man can walk to. [Audience erupts with laughter and applause]

(Callner \& Rock 2008)

The joke transcribed above served as a reminder for me as well as for his concert audiences of how little had changed even when Black artists attained higher levels of economic success. Naming the only four gifted Black artists that live in his neighbourhood and contrasting their career choices and accomplishments with his White neighbour — the "yank-'yo-tooth-out" dentist - Rock helped his audience recognise the nature of the discrepancies that exist for Black and White citizens. Rock laid bare the constraints against which Black people find themselves even as they become wealthier. Rock's analysis implied that simply believing in meritocracy was unwarranted in light of his own experiences as a wealthy comedic actor. Taking this analysis a step further, Rock's discussion of who can afford to live in his community serves to both acknowledge and make visible the structural racism that has saturated the contemporary world. 
Although it may be impossible to explain why a White dentist made as much as one of today's highest earning Black comedians, that this was, in fact, the case indicated that Black people must question claims that America has "risen above racial inequities". By showing how much harder Black people were forced to work to access even a fraction of the material wealth a White person with a "regular" profession had attained, Rock illuminated for his audience the extent to which racism continued to determine where African Americans could and could not afford to live. I knew that Rock, like other Race Comics, had successfully used his comedic prowess to remind audiences that racism continued to structure and organise the lives of Black people in ways that continued to limit their achievement.

As my list of Race Comics expanded, and I became acutely aware that the strategies they employed varied from comedian to comedian, it was slowly becoming clear that one thing connected them and their race comedy work. And that was their work formidable their devotion to ARE principles. Race Comics like Chris Rock, Paul Mooney, Richard Pryor, and Dave Chappelle were committed to ensuring that they hold themselves accountable for their comedy while providing astute, critical, and often uncomfortable social commentaries on the state of race relations through their comedic performances. Race Comics did this by utilising realistic stories as a "hook" for their audiences. Race Comics did this by approaching controversial material in causal ways. Race Comics did this by turning these stories on their head to demonstrate how absurd the underlying ideologies really were. And Race Comics did this by putting their commitment to ARE principles first before any other artistic choice. Their critical pedagogy worked. But one question remained: what would this pedagogical approach add to the teacher education classroom?

\section{The comic intervention: Posing a challenge to the "Perfect Teacher"}

To a large extent, as I reflect upon what I have named my "Comic Intervention", I recognise now that I was not just challenging developing teachers to think and speak explicitly about race. Rather, I was challenging them to think more deeply about what it meant to be a "Perfect Teacher". What did the "Perfect Teacher" think about race? Was the "Perfect Teacher" really colour-blind? Were all students really treated the same regardless of race, ethnicity, sexuality, gender, (dis)ability, and/ or religious affiliation? When did we as "Perfect Teachers" slip, finding ourselves rolling down the slippery slope of stereotypes and race-based assumptions that detracted us from our curricular goals and ambitions? To this end, I decided that laughter might hold the key to unpacking our notion of the "Perfect Teacher". Hypothesising that when something strikes us as funny, is unnerving, or when we are uncomfortable or incredulous, our laughter challenges our ongoing attempts to conceal normalised assumptions by bringing these ideas to the fore, I asked my class to watch various Race Comics who made it their life's work to speak explicitly about race in public forums. Through comedians like Chris Rock and Dave Chappelle, the idea of race and experiences of racism became central topics of discussions. Yet, because I was working with (or we were working through) comedy, I was provided with an opportunity to navigate the treacherous waters of "race talk" by asking developing teachers to think about something else: was what they watched offensive?

During my first Comic Intervention, of the 45 students enrolled in the class, 34 completed consent forms and participated in the two-day session. The sessions were casually presented to students who were told only that participants would be discussing and viewing race-based comedy by "African American comedians". No additional readings were assigned during the 
intervention. The class was divided into small groups of either four or five students, making a total of eight groups for the comic intervention. These groups had been pre-arranged at the beginning of the year, and by the first day of the comic intervention, students had worked closely with their group members for four classes. This arrangement was intended to provide some level of comfort among the participants, who would be asked to discuss the comedic clips assigned in their small group. Each group was provided with two pre-selected clips by a single comedian, with the exception of one group whose clips, though taken from Chappelle's Show, included one sketch featuring Dave Chappelle and a second featuring comedian Paul Mooney, a regular on Chappelle's sketch comedy programme.

While it may appear to be a rather simplistic starting point - a preliminary space which lacked a critical edge - it was surprising how much serious dialogue ensued from the laughter that overtook these classes. More specifically, I was taken aback by the self-reflection that arose just by asking ourselves why something made us laugh. Comedian Donnell Rawlings has suggested that the reason comedy like this works is because it uncovers and lays bare the "inner racism" we contend with on a daily basis. In short, Rawlings suggested that it was through race comedy that viewers could begin to admit that we had all participated (and likely continue to participate) in private, racist dialogues.

Watching controversial comedic material about various racial discourses in our teacher education classroom, I later realised, resulted in many of the students unconsciously comparing what they heard and the dialogues they had while viewing the clips to what could and could not be said in a classroom setting. What we were not entirely prepared for, however, was the recognition that we held some of these perfectly inappropriate views. But, in an attempt to use comedy for social activism, I knew that we had to go there. And with the help of Chris Rock and Dave Chappelle, I know that we did. With each of my "Comic Interventions" I felt increasingly confident arguing that it was the introduction of comedic performances by Black Race Comics that allowed me to ensure that race remained a central concern for us to grapple with. Furthermore, through a close analysis of the comedic texts being introduced in the classrooms, I felt secure proposing that this comedic pedagogy was itself a kind of anti-racist education. And if this is true, it stands to reason that a Race Comic's documented performance on video, DVD, or film could be used as pedagogical resources by classroom teachers to both engage and research the processes of anti-racist education. More specifically, teacher educators could draw upon these resources to challenge developing teachers as they struggled to find ways to reconcile the normalised, hegemonic discourses of race learned over time in their schools and communities with the "messier" experiences of being "raced" and "racing" others in their day-to-day lives.

And I learned something else too. It was a more troubling finding, but one that pointed to something that was needed even more urgently than promoting anti-racist education in teacher education classrooms. Classroom discussions during my first "Comic Intervention" illuminated a need for students to be supported and assisted in recognising how race and racial discourses affected and impacted upon their lives. This lesson was learned while I introduced a simple "ice breaker" to my students in an attempt to find a fun way to delve into our comedic analysis.

The plan was simple: I would begin with a 10-minute activity that involved naming various Black comedians while asking the students to write down everything they knew about the comics named. Although they were not given a lot of time to record their responses, they were informed they could write "I know more than that!" to indicate that they had run out of time but knew more about the comedian in question. The purpose of this activity was not to elicit critical dialogue about the comedians, but was merely an easy, low-pressure introduction to comedy 
legends as we readied ourselves for a more intensive analysis of the pre-selected clips. After listing the names of six Black comedians (i.e., Eddie Murphy, Bill Cosby, Chris Rock, Richard Pryor, Dave Chappelle, and Paul Mooney) and asking the teacher candidates what other "African American" comedians they would include on the list, the following discussion took place: ${ }^{3}$
[Florence]
"Do they have to be Black? Can they be Brown? Russell Peters?"
[Laura Mae]
"Didn't I say African American? I did, right?"
[Group Laughter]
[Laura Mae]
[Florence]
[Laura Mae]
"I have a question. When I say African American..."
"I thought you said ..."
"Hold on, hold on. It's just a question. Hold your horses. [Laughing] It's totally just a question. If I say 'African American,' do you make a distinction between 'Brown' and 'Black'?"
[Whole Class]
"Yes."
[Laura Mae]
"What's the ... can somebody tell me what the distinction is? What's the 'Brown?' What's the 'Black?' What are we talking about?'
[Marvin]
"I think - I don't know for sure - but I think 'Brown' is ... umh Middle East over to India, kind of ..."
[Susie]
[Marvin] "Yeah, that's what 'Brown' is."
[Laura Mae]
"Like East Asia, or West Asia I guess, to India."
[Whole Class]
"Does everybody agree with that?"
[Laura Mae]
"Yes."
"There is consensus?"
[Whole Class]
"Yeah."

Explanations of the physical location from which "Brown" people originated were easily described, even as Marvin attempted to couch his extremely precise geographical location of "Brown-ness" in claims that he was unsure about his definition. That the entire class appeared to agree with the definition provided also helped to illuminate the normalised racial categories used to describe non-White bodies in North America. This shared understanding, however, created an interesting dilemma for the participants, as this fixed definition of race could not be easily superimposed upon the lived realities of their more nuanced encounters with non-White bodies in course readings or in their daily experiences. In an attempt to have the students consider how racial boundaries were consistently being policed, I asked the students to think again about who belonged in the "African American" racial category:

\footnotetext{
[Laura Mae] "When I say ‘African American,' would you put Russell Peters in there?"

[Whole Class] "No"

[Laura Mae] "Why not?"

[Susie]

[Laura Mae]

"Cause he makes the ... He always tells people that he's Indian, and stuff."
"He always makes the jokes that he's Indian and stuff, so ... you ... make the connection ..."
[Norma-Jean] "I think, at least in Canada, or something, that 'Brown' necessarily ... like, it does have a subjective connotation."
[Laura Mae] 'If I say 'African American,' do you put Canadian people in there? Isn't Russell Peters Canadian?"
[Tracy] "He's not Black ..."
[Margaret] "He's not Black ..."




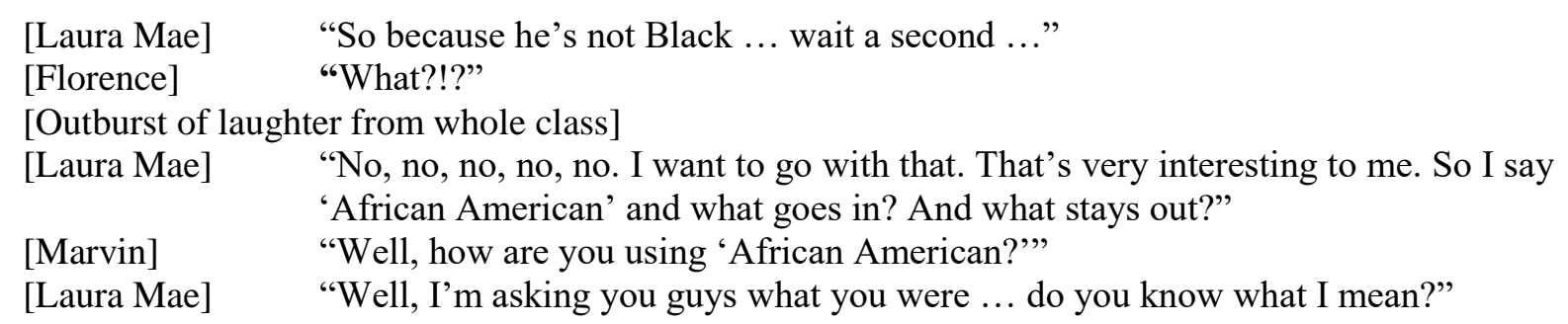

When the students attempted to refer to the fixed racial categories to justify why Russell Peters, a Canadian standup comedian of Indian heritage, should or should not be added to the list of "African American" comedians we were creating, they were faced with the realisation that these racial categories did not allow for the subjective racial and/or ethnic affiliations particular people opted to claim. Thus, Russell Peter's self-identification as "Indian" - this label being considered accurate by the class because of his consistent references to his Indian parents and cultural home life throughout his standup comedy routines - did not easily fit into the unyielding racial boxes we had normalised and were now being asked to use explicitly as we categorised comedians according to race. Moreover, this came into direct conflict with the notion that "real" Canadians were White. This is evidenced by the outburst of laughter when a student claimed that Russell Peters could not be considered "Canadian" because he was not Black. The difficulty involved in talking explicitly about race is a reality that suggests the need for deeper awareness of how individuals categorise "Others".

As the moderator of the discussion, I too held my own assumptions about who should and should not be included within the "African American" racial category and, admittedly, found it difficult to set these aside in order to support my students as they began to recognise that they held differing ideas about who belonged in and outside of particular racial designations. In spite of this, I insisted both implicitly and explicitly to the class that it was imperative that we all recognise that race-based categorisations were consistently being used as we spoke about racial "Others". And I was convinced that the students themselves began to realise this as we looked more and more closely at how race was being deployed in various race comedy clips. One of the strongest examples of this shift in and among my students can be found in the analysis provided of Dave Chappelle's The Racial Draft by students in the Comedic Intervention first conducted in Ontario. More specifically, it was in this critical exploration of The Racial Draft, that students' attempts to reconcile their desire to consider race an irrelevant social category with the challenge to claims of colour-blindness posed by Chappelle's comedic text.

So what happened in The Racial Draft? I believed that the ultimate purpose of the skit was to reveal an American racial paradox: taking pride in the mixed heritage of the American people and an undeniable attempt to classify mixed race people into a single, rigid racial category. To help resolve the paradox, Chappelle imagined a racial draft in which racial groups set out to claim famous mixed-race Americans as one of their own. Struggling to be "perfect teachers", my students, however, were not entirely certain how to interpret Chappelle's work. Moreover, they were not comfortable with what this skit implied about their own views on race, racism, and the "Perfect Teachers" desire to be colour-blind. When asked whether or not the skit "worked", various positions were voiced, all of which revolved around whether or not everyday people agreed or disagreed with the overt racial stereotypes Chappelle discussed in The Racial Draft 2004 (Broder et al. 2005): 
[Vicky] "I think it worked because it ... it wasn't agreeing with the skit [i.e. supporting the racial stereotypes being performed], it was poking fun at how people make these assumptions. And, I think what was funny was how exaggerated they were? Like I don't think people would've laughed if we think it was true. Like ... do you know what I mean? If ... if that's how we actually saw different races, and different religions, I don't think it would've been funny. I think it was funny because we were like, 'Oh, that's ridiculous."'

Chanel quickly challenged Vicky's statement:

[Chanel]

"I kind of disagree with that. I think that that's how people really do see it. Like I think that people really do categorize people like that ... and look at ... like, if someone is multiracial, if you want to call it that, like they do look at it from either side. And I think that that's shedding light ... like making us look foolish — that's really what we're doing, like inside our head, you know, not saying it out loud, but ... yeah."

Both Vicky and Chanel provided commentary about the clip that made plain the struggle of the students taking part in the intervention. While Vicky's comments reiterated the opening claims from many classmates that they did not "believe" in the exaggerated stereotypes typically attributed to members of the fixed racial categories Chappelle discussed in The Racial Draft, Chanel suggested that what is really at issue is the fact that we do make these types of race-based assumptions privately, "in our heads". Moreover, when people legitimately cross racial boundaries because of their mixed heritage, it was an internal and normalised system of classification that resulted in attempts to place themselves into a single, rigid, racial category. Although the students indicated in classroom discussions that they found Chappelle's use of exaggerated racial stereotypes offensive, none of the teacher candidates participating in the comic intervention considered that these stereotypical representations aimed to shed light on what it meant to be "drafted" into a particular race. In short, the manner of dress, speaking, and the assumptions these held for people of other races were part of the "welcome (racial) package" given to newly acquired members of the (racial) team. In spite of the resistance to thinking of Chappelle's sketch in this way, I believed that a number of the students were taking steps to consider racial designations with much more profundity as the discussion continued. For example, one student explained, "we just accept the stereotypes that are placed upon us, and don't ... stand up to argue otherwise against them. [...] We laugh because it's such a reality [...] and it's so true".

While students continued to think seriously about the ideas presented by Race Comics, it became apparent that they hoped that their laughter at these difficult images and uncomfortable sketches was indicative of transcending race and racism:

[Patrick] "I think the reason we laugh and stuff is ... we laugh at things that are edgy, or that cross the line. It's almost like, you know, escapist, so ... and I think that's the reason why we laugh at some of these things. And I think another reason we laugh is that, maybe we're over, like, not totally over, but over, like hate or racism, that we can ... we can actually laugh at things like this, and not be offended, so ..."

Patrick's explanation of why we laugh suggested that laughter at race-based comedy indicates that "it" is a non-issue for audiences. This interpretation, however, led to a dismissal of some of 
the group's opinions about race. For example, the group charged with initially viewing and presenting the clip to the full class explained that they did not like that in Chappelle's sketch, "'Jews' were considered a race". Although various steps were taken to encourage students to be accountable for their opinions about race throughout the intervention including writing their opinions down and taking on the role of "expert" in front of the larger group, the group did not explain why they did not like that Chappelle's sketch considered being Jewish as a racial category, nor did anyone in the larger group ask for clarification on this point. Was it that the intensity of the conversations held about race made it difficult to sustain student accountability? Would students always be more inclined to revert back to the "safe" position of denying race as a category - even if it meant a denial of a complicated historical reality that resulted in a group of people taking pride in their racial affiliation? It seemed clear that this position also allowed the students to deflect any suggestion on my part that they might be implicated (and likely were, as we all are) in the seriously negative socio-political consequences that are a part of the lived reality of raced bodies in a racist world. Thus, attempts like Patrick's to argue that racism no longer existed in the contemporary world were likely symptomatic of the strength of hegemonic racial ideologies which aimed to maintain racial inequities under the guise of social justice and/or racial transcendence.

It was also interesting to seriously consider the role of laughter throughout our sessions, specifically because it was through laughter that the strongest link between race comedy's possibilities and an educator's imagined perfection qua teacher was most easily established. For example, one student expressed that she found The Racial Draft (Broder et al. 2005) offensive, but was much more concerned with trying to understand and give voice to her embarrassment when she realised that she was unable to stop herself from laughing at something she believed was highly offensive.
[Florence]
"I was just offended by the whole thing."
[Laura Mae]
"Were you offended by the whole thing?"
[Florence]
"And I was laughing. But it was also offensive. And I was just like, 'Oh my God, why am I laughing? This is so embarrassing."

In an effort to help her reconcile her feelings about the immediate reaction to the clip, I suggested that we had all experienced a moment similar to Florence's where we laughed at something that we felt was inappropriate. I asked the class to think about why we laughed at these controversial portrayals. Bertha's response stood out for me:

[Bertha] 'I think the reason why we laugh is because, when you're in public, and it's said as a joke, or witnessing it as a 'fact' or a stereotype, you don't laugh cause you're scared you might offend people, but when we're watching it ... it's like, it's a comedy show, so we're ... like ... expected to laugh. So when we see these things, we finally get to laugh".

It is possible that Florence was made uneasy by her laughter at the clip because it directly contradicted the presumed political correctness a "good" classroom teacher would display (i.e., that we do not laugh at offensive material). Bertha's comment that "we finally get to laugh" makes visible this tension as the students were charged with the uncomfortable task of viewing the edgy performances of Race Comics. By offering them a context in which their laughter was considered acceptable, and where they were also able to think about why they laughed, the 
students were granted a well-needed opportunity to critically assess the role race plays in their daily lives.

In light of the pre-service teacher dialogues that arose even before the class discussed the performances of select Race Comics, it was clear that students were only just beginning to recognise what the old categories of racial distinctions meant for them. It was only through continual dialogue that students began to seriously consider the role of racial distinctions in Canadian society while re-thinking their initial sentiments that crossing racial boundaries was easily achieved. Without the ability and opportunity to reflect upon how race operates in contemporary society, no changes to definitions, theories, and praxis about race will make a difference for today's students.

Telling our students that the old racial categories no longer work to explain contemporary racial realities or proposing to them that new definitions and theories of "race" are needed, assumes that the students know how the old categories worked in their worlds in the first place. Unfortunately, it appears that the emphasis in teacher education classrooms to keep discussions in the realm of theory (if or when race is discussed) serves only to reinforce students' simplistic understanding of old, fixed racial categories placed on themselves and each other. This is not to say that re-thinking how race operates today is a useless endeavour, but only to suggest that before this can be done effectively for students, teachers, and pre-service teacher candidates, more space must be created to help students talk about their experiences as raced bodies in the world, a point that many ARE scholars come back to time and again in their work (LadsonBillings 1995, 2009a, 2009b, 2009c; Solomon \& Levine-Rasky 1996, 2003; Earick 2009).

\section{Final thoughts}

There is only one more lesson that I would like to share. One more thought based on my "Comic Interventions" that is worth taking a moment to reflect upon: the Race Comic's inherent adherence to a particular notion of social responsibility. I would argue that for the Race Comics introduced in my teacher education classrooms, they each felt a responsibility to their fans, to their friends, and to their families, and it was this responsibility that pushed them to use their art to change their world. What they did and the art they produced can have serious effects on future variations of anti-racist education, and for a Race Comic it is what their comedy does "on the ground" that is truly symbolic of success. In a similar vein, many teachers believe that anti-racist education has been successfully addressed in schools as long as race has been "taught" to their students. But what exactly does this look like? For me, anti-racist education has become much more than simply telling students that we live in a world where "race matters", although explaining that to students is certainly a part of what I do. Anti-racist education has become an opportunity for me to open up my classrooms to dialogues about our real experiences with race. Sharing personal stories, drawing on particular moments when race mattered and spending time talking about how these experiences have shaped us is very important for "successful" anti-racist experiences.

Doing this work in schools, of course, is not without its challenges. Anti-racist educators devote large amounts of time and energy to the struggle against proponents of those systemic pressures that would have them focus on the "real" curriculum and leave the social justice and equity topics for their designated times (i.e., during Black History Month or Multicultural Week). For Black educators interested in doing ARE work, other pressures abound including resistance from students who maintain that such discussions are no longer necessary. The 
following statements made during the comic intervention by two separate participants demonstrate this:

Why in this course are we so drawn to ethnic/visual/cultural/any type of minorities in this course? Are we leaving out the "regular, mainstream" students who will ALSO be in our classrooms?

(Pre-service Teacher 2010)

If we ignore racism - like, as a concept in our brains ... if it doesn't exist as a concept, to anyone then, it will just go away.

(Pre-service teacher 2010)

The quotes above best reflect the point of departure for teacher education students when pushed to critically assess discourses of race and racism in their schools. From resistance to seeing the need to more vigorously consider the experiences of "Othered" students in the educational system, to unadulterated support for colour-blind discourses, I am consistently reminded of the necessity to continue to develop and implement anti-racist work in my classes. The urgent need for this ongoing work is beautifully articulated by bell hooks (2003) in her text Teaching Community: A Pedagogy of Hope:

Teachers are often among the group most reluctant to acknowledge the extent to which whitesupremacist thinking informs every aspect of culture including the way we learn, the content of what we learn, and the manner in which we are taught. Much of the consciousness-raising around the issue of white supremacy and racism has focused attention on teaching what racism is and how it manifests itself in the daily workings of our lives. In anti-racist workshops and seminars, much of the time is often spent simply breaking through the denial that leads many unenlightened white people, as well as people of colour, to pretend that racist and white-supremacist thought and action are no longer pervasive in our culture.

(hooks 2003: 25)

Notably we must continue to rise up in the face of these ongoing challenges to invest the time, energy, and expertise to remind developing teachers that race does play a critical role in their lives and in the lives of their students. And comedy helps to open us up to ideas, forces us to consider new perspectives, and, when performed effectively, asks us to recognise when our normalised beliefs no longer make sense. Comedy asks us to question why we laugh while we laugh, freeing us from the constraints that force us to verbalise politically correct responses that may or may not be in line with how we really feel. It is within the folds of this act of freedom that I believe the most interesting and important anti-racist work can be developed.

\section{Notes}

1 In spite of differences between anti-racism and critical race theory, both approaches address the role(s) race and racism play in North America. I acknowledge that the birth of critical race theory from critical legal studies in the United States of America, and anti-racism education's focused attention on addressing continued racial inequities in educational institutions do support a different analytical approach to the field. However, for simplicity I will refer to both sets of scholarship as "ARE". When introducing a particular scholar's work, however, I will refer to either anti-racist education or critical race theory based on how they have chosen to frame their theorising. 
${ }^{2}$ Haggins defines "post-soul" as the time period after Black power movements in America, acknowledging that this term was coined by cultural critic Nelson George (Haggins, 2007: 4).

${ }^{3}$ Student names have been changed to protect the privacy of participants.

${ }^{4}$ Russell Peters self-identifies as a Canadian comedian whose parents are Indian or of South Asian descent.

\section{References}

Bell, D. (1992). Faces at the Bottom of the Well: The Permanence of Racism. New York: Basic Books.

Bell, D. A. (2009). 'Who's afraid of critical race theory?', in Taylor, E., Gillborn, D. \& LadsonBillings, G. (eds.), Foundations of Critical Race Theory in Education, New York: Routledge, pp. 37-50.

Bell-Jordan, K. (2007). 'Speaking fluent "joke": Pushing the racial envelope through comedic performance on Chappelle's Show'. Performance Research 12 (3), pp. 74-90.

Boler, M., \& Zembylas, M. (2003). 'Discomforting truths: The emotional terrain of understanding difference', in Trifonas, P. (ed.), Pedagogies of Difference: Rethinking Education for Social Change, New York: Routledge Falmer, pp. 110-136.

Britzman, D. (1998). Lost Subjects, Contested Objects: Toward a Psychoanalytic Inquiry of Learning, Albany: State University of New York Press.

Broader, T. (Director), \& Chappelle, D., Rawlings, D., Murphy, C., \& Brennan, N. (Writers). (2005). Chappelle's Show: Season 2 Uncensored. United States: Comedy Central.

Callner, M. (Director), \& Rock, C. (Writer). (2008). Chris Rock: Kill the Messenger [DVD]. United States: CR Enterprises.

Carby, H. V. (1998). Race Men. Cambridge: Harvard University Press.

Chase, S. E. (2010). Learning to Speak, Learning to Listen: How Diversity Works on Campus. Ithaca: Cornell University Press.

Comedy Central. (Writer). (2006). Chappelle's Show: The Lost Episodes [DVD]. USA: Paramount Pictures.

Danesi, M. (2008). Popular Culture: Introductory Perspectives. New York: Rowman \& Littlefield.

DiFranco, J., \& Eldridge, S. (2013). 'Antiracist teaching under fire in public schools: A case study'. Understanding \& Dismantling Privilege: The Official Journal of The White Privilege Conference and The Matrix Centre for the Advancement of Social Equity and Inclusion 3 (1), pp. 173-190.

Earick, M. E. (2009). Racially Equitable Teaching: Beyond the Whiteness of Professional Development for Early Childhood Educators. New York: Peter Lang.

de Freitas, E. \& McAuley, A. (2008). 'Teaching for diversity by troubling whiteness: Strategies for classrooms in isolated white communities'. Race Ethnicity and Education 11 (4), pp. 429442.

Gardner, J. (2014). 'Slashed wrists, sex with prison guards and a jailhouse lesbian lover: Inside the twisted world of Susan Smith 20 years after she drowned her sons and blamed "a black man"'. Mail Online, Available online: http://www.thegrio.com/slideshow/blame-it-on-blackinfamous-racial-crime-hoaxes.php [Accessed on 28 October 2015]. 
Haggins, B. (2007). Laughing Mad: The Black Comic Personae in Post-Soul America. New Jersey: Rutgers University Press.

Henry, A. (2000). 'Black women teachers' positionality and "everyday acts": A brief reflection on the work to be done', in Dei, G. J. S. \& Calliste, A. (eds.), Power, Knoweldge and AntiRacism Education: A Critical Reader, Halifax: Fernwood Publishing, pp. 93-97.

hooks, b. (2003). Teaching Community: A Pedagogy of Hope. New York: Routledge.

Jabali-Nash, N. (2010). 'Acid attack hoax "victim" Behtany Storro charged with theft'. CBS News, Available online: http://www.cbsnews.com/8301-504083_162-20017099-504083.html [Accessed 28 October 2015].

Ladson-Billings, G. (1995). 'Toward a theory of culturally relevant pedagogy'. American Educational Research Journal 32(3), pp. 465-491.

Ladson-Billings, G. (2009a). 'Fighting for our lives: Preparing teachers to teach African American students', in Darder, A., Baltodano, M. P. \& Torres, R. D. (eds.), The Critical Pedagogy Reader, $2^{\text {nd }}$ ed., New York: Routledge, pp. 460-468.

Ladson-Billings, G. (2009b). 'Just what is critical race theory and what's it doing in a nice field like education?', in Taylor, E., Gillborn, D. \& Ladson-Billings, G. (eds.), Foundations of Critical Race Theory in Education, New York: Routledge, pp. 17-36.

Ladson-Billings, G. (2009c). 'Race still matters: Critical race theory in education', in Apple, M. W., Au, W. \& Gandin, L.A. (eds.), The Routledge International Handbook of Critical Education, New York: Routledge, pp. 110-122.

Lea, V., \& Sims, E. J. (eds.). (2008). Undoing Whiteness in the Classroom: Critical Educultural Teaching Approaches for Social Justice Activism. New York: Peter Lang.

Littleton, D. (2006). Black Comedians on Black Comedy. New York: Applause Theatre \& Cinema Books.

Lindo, LM (2015). 'The whiteness of philosophy: Imagining non-white philosophy in schools', in Lund, D. E. \& Carr, P. R. (eds.), Revisiting the Great White North? Reframing Whiteness, Privilege and Identity in Education $2^{\text {nd }}$ ed., Rotterdam, The Netherlands: SENSE Publishing, pp. 229-240.

Lindo, LM. (2007). 'Whiteness and philosophy: Imagining non-white philosophy in schools'. in Carr, P. R. \& Lund, E. E. (eds.) The Great White North? Exploring Whiteness, Privilege and Identity in Education, Rotterdam, The Netherlands: SENSE Publishing, pp. 189-198.

Lindo, LM (2010). 'Comic revelations: Antiracist pedagogy under pressure', in Smith, C. C. (ed.), Anti-racism Education: Missing in Action Ottawa, Ontario: Our Schools/Ourselves, Canadian Centre for Policy Alternatives, pp. 185-198.

Mayo, C. (2008). 'Being in on the joke: Pedagogy, race, humour'. Philosophy of Education, pp. 244-252. Available online: http://ojs.ed.uiuc.edu/index.php/pes/article/view/1372/122 [Accessed 28 October 2015].

McNair, J. (2007). "I may be crackin', but um fackin": Racial humour in The Watsons go to Birmingham - 1963'. Children's Literature in Education 39 (3), pp. 201-212.

Means Coleman, R. R. (2000). African American Viewers and the Black Situation Comedy: Situating Racial Humor. New York: Garland Publishing.

Mooney, P. (Writer/Performer). (1993) . Race [Stand-up comedy CD]. United States: Novamute.

Nachman, G. (2003). Seriously Funny: The Rebel Comedians of the 1950s and 1960s. New York: Pantheon Books.

Pryor, R., \& Gold, T. (1995). Pryor Convictions and Other Life Sentences. New York: Pantheon Books. 
Ramsey, G. P., Jr. (2003). Race Music: Black Cultures from Bebop to Hip-Hop. Berkeley, CA: University of California Press.

Reporter. (2010). 'Sgt. Robert Ralson shot himself and lied, saying unidentified black male did it', Hinterland Gazette, Available online: http://hinterlandgazette.com/2010/05/sgt-robertralston-shot-himself-and.html [Accessed 28 October 2015].

Rotenberg, M., Rock, C., Chanley, S., Bull, T. (Producers), \& Truesdell, K. (Writer/Director). (1996). Bring the pain [DVD]. United States: Universal.

Solomon, R. P., \& Levine-Rasky, C. (2003). Teaching for Equity and Diversity: Research to Practice. Toronto: Canadian Scholars' Press.

Sutherland, M. (2008). The Flip Wilson Show. Detroit, MI: Wayne State University Press.

Washington, V. (1981). 'Impact of antiracism/multicultural education training on elementary teachers' attitudes and classroom behaviour'. The Elementary School Journal 81 (3), pp. 186192.

Watkins, M. (1994). On the Real Side: Laughing, Lying, and Signifying - The Underground Tradition of African-American Humour that Transformed American Culture from Slavery to Richard Pryor. New York: Simon \& Schuster.

Watkins, M. (ed.). (2002). African American Humour: The Best Black Comedy from Slavery to Today. Chicago: Lawrence Hill Books.

Woolfork, L. (2009). Embodying American Slavery in Contemporary Culture. Urbana: University of Illinois Press

Zenovich, M. (Writer) (2013). 'Richard Pryor: Omit The Logic', in Ackerman, R. \& Pryor, J. (Producers), United States of America: Fresh One Productions \& Tarnished Angel.

Zoglin, R. (2008). Comedy at the Edge: How Stand-Up in the 1970s Changed America. New York: Bloomsbury. 